\title{
Social representations of patients with vasculogenic ulcers about quality of life: an analysis of the social context
}

\author{
Representações sociais de pacientes com úlceras vasculogênicas sobre qualidade de vida: análise do contexto social
}

Representaciones sociales de pacientes con úlceras vasculogénicas sobre la calidad de vida: análisis del contexto social

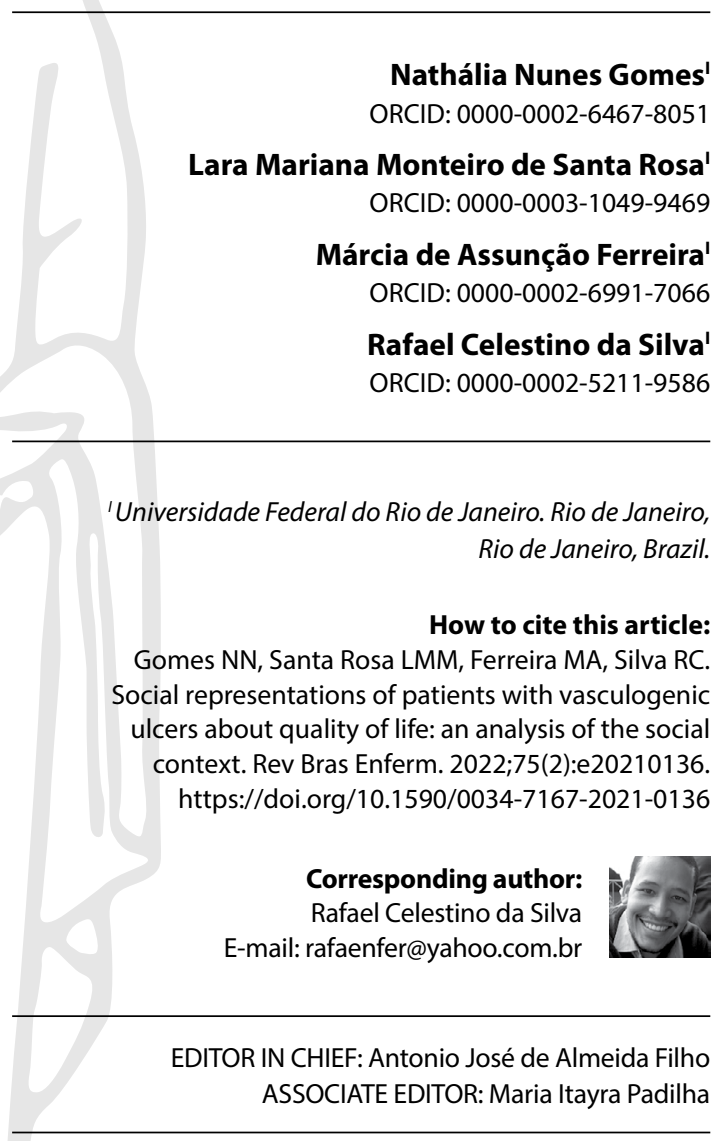

Submission: 11-07-2020
Approval: 05-27-2021

\section{ABSTRACT}

Objective: to describe the social representations of patients with vasculogenic ulcers about quality of life and analyze such representations from the social context of patients insertion in relation to the healthcare service. Method: a qualitative research, based on social representations, developed in a Family Clinic in Rio de Janeiro with 30 patients with vasculogenic ulcers for over 90 days. Data were produced through interviews and submitted to lexicographical analysis using the Alceste software. Results: the weaknesses of care in the healthcare service to which patients were linked contributed to exacerbate the reconfiguration of daily life that the occurrence of ulcers implies, due to the presence of pain and physical restrictions, influencing the representation of quality of life. Final considerations: the representation was objectified as a counterpoint to the image of "being happy", and actions expressed proactivity in the search for a cure or passivity due to lack of clinical results. Descriptors: Varicose Ulcer; Nursing; Primary Healthcare; Patient Care Team; Wounds and Injuries.

\section{RESUMO}

Objetivo: descrever as representações sociais de pacientes com úlceras vasculogênicas sobre a qualidade de vida e analisar tais representações a partir do contexto social de inserção dos pacientes em relação ao serviço de saúde. Método: pesquisa qualitativa, pautada nas representações sociais, desenvolvida em uma Clínica da Família do Rio de Janeiro com 30 pacientes com úlceras vasculogênicas há mais 90 dias. Os dados foram produzidos por entrevista e submetidos à análise lexicográfica com auxílio do software Alceste. Resultados: as fragilidades do atendimento no serviço de saúde em que os pacientes estavam vinculados contribuíram para exacerbar a reconfiguração do cotidiano que a ocorrência da úlcera implica, pela presença da dor e restrições físicas, influenciando na representação sobre a qualidade de vida. Considerações finais: a representação foi objetivada no contraponto da imagem de "estar feliz", e as ações expressaram proatividade na busca pela cura ou passividade pela falta de resultados clínicos.

Descritores: Qualidade de Vida; Úlcera da Perna; Assistência à Saúde; Psicologia Social; Cuidado de Enfermagem.

\section{RESUMEN}

Objetivo: describir las representaciones sociales de los pacientes con úlceras vasculogénicas sobre la calidad de vida y analizar dichas representaciones desde el contexto social de inserción de los pacientes en relación al servicio de salud. Método: investigación cualitativa, basada en representaciones sociales, desarrollada en una Clínica Familiar en Río de Janeiro con 30 pacientes con úlceras vasculogénicas durante más de 90 días. Los datos se produjeron a través de entrevistas y se sometieron a análisis lexicográfico utilizando el software Alceste. Resultados: las debilidades asistenciales en el servicio de salud al que estaban vinculados los pacientes contribuyeron a exacerbar la reconfiguración de la vida cotidiana que implica la aparición de úlceras, por la presencia de dolor y restricciones físicas, incidiendo en la representación de la calidad de vida. Consideraciones finales: se objetivó la representación como contrapunto a la imagen de "ser feliz", y las acciones expresaron proactividad en la búsqueda de una cura o pasividad por la falta de resultados clínicos.

Descriptores Calidad de Vida; Úlcera de la Pierna; Prestación de Atención de Salud; Psicología Social; Atención de Enfermería. 


\section{INTRODUCTION}

In the holistic approach, the concept of quality of life (QoL) is understood as multidimensional, differing from person to person according to context, and its components have a complex and dynamic organization. Among the components that define QoL in this broader perspective are "being", what the human being is in the individual field, which has to do with the physical, psychological and spiritual, encompassing nutrition, physical fitness, values, individual skills, experiences; "belonging", which refers to connections with the environment, home, work, community, social groups; and "becoming", what the person does to achieve their goals, involving leisure practices, personal growth, skill development ${ }^{(1)}$.

Considering this conceptual scope, it starts from the understanding that the occurrence of a vasculogenic ulcer, the focus of the research in question, causes changes in the dimensions of their QoL in patients ${ }^{(2)}$. This type of leg injury, in most patients, is chronic in nature, that is, they are injuries that persist for more than six weeks and do not tend to heal after three months or more of treatment. Therefore, it constitutes a serious health problem for the human being ${ }^{(3)}$.

Vasculogenic ulcers account for $95 \%$ of all types of chronic injuries and affect 0.6 to $3 \%$ of people over 60 years and more than $5 \%$ of those over 80 years of age ${ }^{(3)}$. In Brazil, a study that traced the epidemiological profile of 53 patients with venous ulcers showed a predominance of individuals over 60 years old, female and with chronic diseases ${ }^{(4)}$.

Analysis of production of national and international knowledge on this topic ${ }^{(2,5-7)}$ indicated the physical domain, functional capacity and social aspects as the dimensions of QoL most affected in these patients, due to the physical repercussions, pain, immobility, disability, stigmas, prejudices and aspects related to self-esteem and self-image ${ }^{(5-9)}$. Furthermore, in addition to spending on health, vascular ulcers also impact the expenses generated by retirement and death of an economically active population ${ }^{(2,10-11)}$.

Such impacts on QoL arouse many affections in patients. Nowadays, there is a social construction of the body in which beauty, the young and healthy body is valued. This social image of an ideal body influences self-image. Thus, the social standards that dictate what is and what is not acceptable condition the way one perceives the body and appearance ${ }^{(12)}$.

From this perspective, in the case of patients with vasculogenic ulcers, faced with this imagery dimension, negative effects on their bodies arise. An example of this is that studies show that patients out of "shame" or fear of being discriminated against are socially excluded ${ }^{(9,13)}$. It should be noted that the affective dimension is the basis of familiarity with the social belonging group. So, when an object provokes such a group, the subjects who identify with it want to participate in the conversation circuit mobilized by the object to feel included, to be recognized, to be able to communicate using a common language ${ }^{(14)}$.

In this understanding, affections are essential to the elaboration of social representations (SR) from this conversation, which organizes cognitions or evaluative behaviors ${ }^{(14)}$. Such SR are built in the universe of common sense by those who share ideas and interpretations of the world, thus, they articulate the social and the psychological, which guide the formation of social thinking that precedes behavior ${ }^{(15)}$.
In patients with vasculogenic ulcers, given the impacts of the disease, the phenomenon of QoL is imbricated in their daily lives, being the object of relevance for this social group, as it generates conversations and assessments among patients about their insertion in different spaces of life. These constant exchanges of information and experiences lead to the development of common sense knowledge about QoL, which expresses the relationships they experience, brings the marks of this group and guides social practices, i.e., it affects decisions about relating to the other is about the goals of life, being a phenomenon of $S R^{(15)}$.

Based on this understanding, it is considered that the inclusion of patients in the healthcare service and the meeting of their demands by professionals have a relevant role in these SR on QoL, since in the difficulties that arise in this process, often neither the person nor are the family prepared to understand the aspects that involve this problem.

International investigations have pointed out the impacts of professionals' work on the QoL of patients with vasculogenic ulcers $^{(7,16)}$. In a case study developed in the United Kingdom, psychosocial interventions made by healthcare professionals contributed to reduce the stress of living with a venous leg ulcer to improve coping skills and, subsequently, improve wound healing ${ }^{(7)}$.

In the American survey, which described the experience of patients with chronic venous insufficiency, to explore how this chronic disease affects health-related QoL, participants cited the lack of knowledge about chronic venous insufficiency in the nonspecialized health team as a factor. contributory to the decrease in $\mathrm{QoL}^{(16)}$.

Therefore, patient assessment by the team is essential to analyze the progress of therapy, indicate the need for reassessment of treatment and implement new technologies in the wound care area. Furthermore, it is essential to support adherence to new lifestyle habits, in the prevention of complications and in the rehabilitation processes ${ }^{(17)}$.

SR are prepared by people who are part of a sociocultural group and are inserted in a certain context. Therefore, in SR, the social context influences the symbolic elaboration of the phenomenon ${ }^{(15)}$. This time, starting from the problematization and in the light of this theoretical premise, the question was: how is the elaboration of SR of patients with vasculogenic ulcers on QoL considering the social context of insertion of such patients in relation to the healthcare service in who are linked?

\section{OBJECTIVE}

To describe the social representations of patients with vasculogenic ulcers about quality of life and analyze such representations from the social context of patients' insertion in relation to the healthcare service.

\section{METHOD}

\section{Ethical aspects}

The project was approved by the Institutional Review Board of the field of study. Participants signed the Informed Consent 
Form, maintaining the numerical coding generated by Alceste to guarantee confidentiality, plus the participant number according to the order of admission, in which Ind means individual.

\section{Study design and theoretical-methodological framework}

This is a qualitative approach research, developed with the support of COREQ ${ }^{(18)}$. The theoretical-methodological framework was the theory of SR, in its procedural approach. In this, information matters, which deals with the knowledge of a group about a social object; the attitude, which focuses on the global orientation towards the object; and the field, which refers to the social model of the object of $\mathrm{SR}^{(15)}$.

\section{Research setting}

The study was carried out in a Family Clinic in the city of Rio de Janeiro. This unit is a pioneer in the model of primary care focused on prevention, health promotion and early diagnosis of diseases, with the offer of different services provided by a multidisciplinary team to families registered in Family Health Teams linked to the clinic.

The Family Clinic, locus of the investigation, had eight complete Family Health Teams, three Oral Health Teams, in addition to the entire apparatus of Academia Carioca da Saúde. The clinic had approximately 36,256 registered patients, and performed different types of care: medical and nursing consultations, specialized treatment, immunization, prenatal care, active search for injuries, health promotion actions in schools and social entities in the area, aiming at maintaining the enrolled families' health.

The locus of research was the unit's dressing room, which had patients with vasculogenic ulcers as one of the target audiences. At the time of data production, 86 patients were registered in this sector, with an average of 20 consultations per day. The care provided by professionals in the dressing room was carried out in the morning and afternoon shifts, according to the order of arrival of patients. Waiting time varied, on average, from 30 to 50 minutes, with a lower flow of assistance in the afternoon. Patients attended the unit daily to perform the dressing, and on weekends, they performed it at home.

The service in the sector was provided by nursing technicians and a nurse. In the case of nursing technicians, they were responsible for performing the dressing and providing guidance to patients about general care for the injury. In the first care of patients in the dressing room, all went through a nursing consultation with a nurse, a specialist in stomatherapy. Subsequently, nursed assisted patients, when requested by a nursing technician, to assess the injury and decide on the nursing conduct, particularly in cases of injury aggravation. The dressings used in dressings, in general, were less advanced, but there were periods when more complex dressings were available, such as foams with silver and alginates. In addition to monitoring by the nursing team, patients were monitored by a general practitioner of the unit, who, after clinical assessment, referred patients for consultation with an angiologist. However, at the time of research, not all patients had been seen, due to the delay in scheduling the consultation through the municipal regulation system.

\section{Data source}

Participants were patients registered at the chosen clinic, selected by the criteria: over 18 years old; no motor limitations in speech; medical diagnosis of vasculogenic ulcer in the lower limbs for a period longer than 90 days, after which the injury is considered chronic. From this group, the following were excluded: those with chronic or severe comorbidities (decompensated heart disease, paraplegia and morbid obesity), due to the potential of these conditions to affect QoL and, consequently, in the elaboration of SR; and with cognitive deficit, assessed by the coherence of answers and reasoning logic based on the questions that were made by the researcher during the field exploration and participant capture phase.

\section{Data collection, organization and analysis}

The research was developed with 30 patients, captured after two weeks of approaching the locus sector of the study, in which general characteristics of the unit and the list of patients with vasculogenic ulcers were registered in a field diary. This was obtained from the care record book, which contained the ulcer classification based on the medical diagnosis in the medical record. Then, an invitation to participate and scheduling of data production was carried out.

Data production took place from September 2017 to January 2018. The data collection technique was a semi-structured interview, carried out after patients had applied the dressing, in a room attached to the dressing sector, with the aid of a digital device and an average duration of thirty minutes. Prior to its realization, a pilot test was carried out with two patients who did not integrate the final corpus of the research to assess the instrument, which did not show the need to change the questions. This time, a script was applied that included a first part with questions to know the social belonging of the studied group, namely: age, wound time, religion, education, professional activity, family income, leisure/physical activity.

The second part consisted of open-ended questions about patients' daily lives: talk a little about your daily life living with a leg ulcer; what is good in this daily life? Are there difficulties for you to fulfill your activities? If yes, which? What do you do to overcome them? What was your life like before and after having a wound like the one you have? What do you think needs to be done for a person who has this wound to live better and solve problems? What do you do? Is it possible to live well even with this type of wound? Is there something missing to improve your daily life that worries you? Could someone help so you can live better? Who can contribute and how? Tell us a little about the relationship between the healthcare service and the person who has an ulcer.

Data collection was completed with 30 participants, as there was an interruption of operation in the unit studied during the research period, due to lack of inputs. Therefore, an analytical immersion was carried out to evaluate the collected material, concluding that it had sufficient density to understand the phenomenon and dimensions of SR. Furthermore, this number meets the consensus among scholars of the qualitative approach on the 
adoption of a minimum quantity of 30 participants for analysis with density of the phenomenon ${ }^{(19)}$.

The sociodemographic profile data were crossed with the discursive production about the research object. Thus, they supported the elaboration of a line of identification of the deponent that separated each interview from the corpus. From this, a cross was made using the software Alceste, which processed the interviews through lexicographical analysis. In this analysis, we sought to understand the structural organization of patients' discourses, taking as reference the vocabularies used by them, which constituted a trace of intention to make sense of the phenomenon studied.

The lexical analysis was done with the 2012 version of Alceste, in the form of standard processing. For this purpose, the research database was organized after the transcription of the 30 interviews and their preparation, following the program's criteria. Each interview was considered an initial context unit (ICU), stored in a single file that constituted the corpus of the research. In the executed processing, the software grouped the semantic roots of the words used, analyzed their function and occurrence/co-occurrence within the corpus. In this process, the text was divided into discursive fragments, called elementary context unit (ECU), and Alceste crossed the lexicons in the ECU, defining classes from typical lexicons that showed greater association with these classes, measured by the value of chi-square (Phi).

The interpretation was based on the Factorial Correspondence Analysis (FCA) and Descending Hierarchical Classification (DHC). The FCA presents the distribution of classes in a factorial plane, allowing a broad view of assessment of the oppositional relationships between them. In DHC, the relationships of intraclass, interclass and between class chunks are interpreted.

\section{RESULTS}

Regarding the participants" sociodemographic profile, the following characteristics stood out: $60 \%$ of women; $50 \%$ married; $50 \%$ between 51 and 70 years old; $57 \%$ with family income between two and three minimum wages; $70 \%$ with incomplete elementary school; $45 \%$ with injury time between three and ten years; $47 \%$ Evangelicals; $90 \%$ without physical activity; $67 \%$ without professional activity.

The corpus was divided into $679 \mathrm{ECU}$, and, in two descending hierarchical classifications, kept the same subdivision into two chunks of classes, with a total of five lexical classes and $63 \%$ use, as shown in Figure 1. In this figure, it is observed that the chunk that brought together Classes 1 and 2 was the first to be formed, representing $70 \%$ of the corpus. This chunk distanced itself from the chunk of Classes 3,4 and 5, responsible for a smaller portion of the corpus, and which had Class 5 as the most representative of this chunk.

In Figure 2, the distribution of classes in the factorial plane into two axes is observed, Axis 1, in the horizontal line, which revealed the highest factor loadings (33\%), and Axis 2, in the vertical line, which accounted for $26 \%$. Together, the two axes explained $59 \%$ of the ECU variance. It is also possible to visualize the distribution of semantic fields opposite to the two axes from the words with the highest factor loadings. Thus, in Axis 1, in the negative pole on the left, are the lexicons of Classes 4 and 5, which expressed the daily lives of these patients (agreement, coffee, lunch, machine), and the physical repercussions arising from the impact of the disease (pain, lying down, sitting, sleeping). On the positive side, there are the lexicons present in class 1 (problem, treatment, cure), which revealed the challenges for accessing treatment. In Axis 2, on the upper level, the lexicons reflected the role of nursing in the application of care techniques and technologies (technical, nursing, assisted - Class 2), and on the lower level, the social impacts (party, bus, children - Class 03), faced by patients with ulcers.

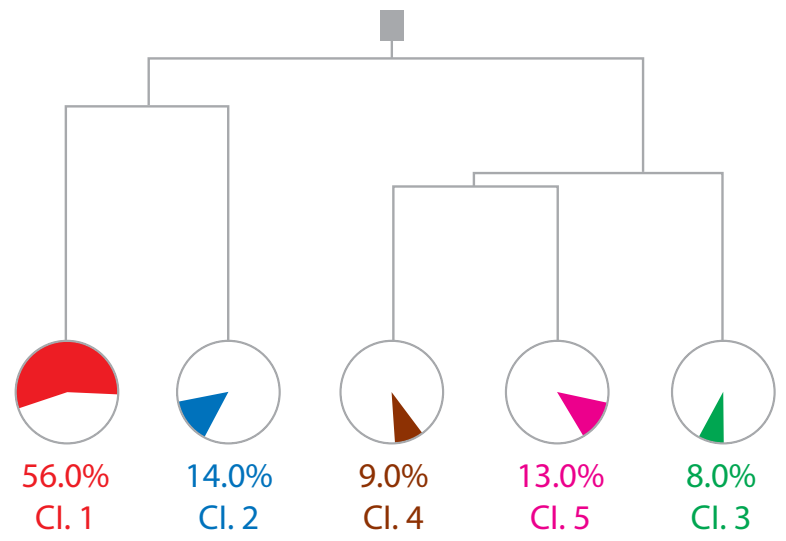

Source: Alceste report.

Figure 1 - Partition process of the corpus, Rio de Janeiro, Rio de Janeiro, Brazil, 2018

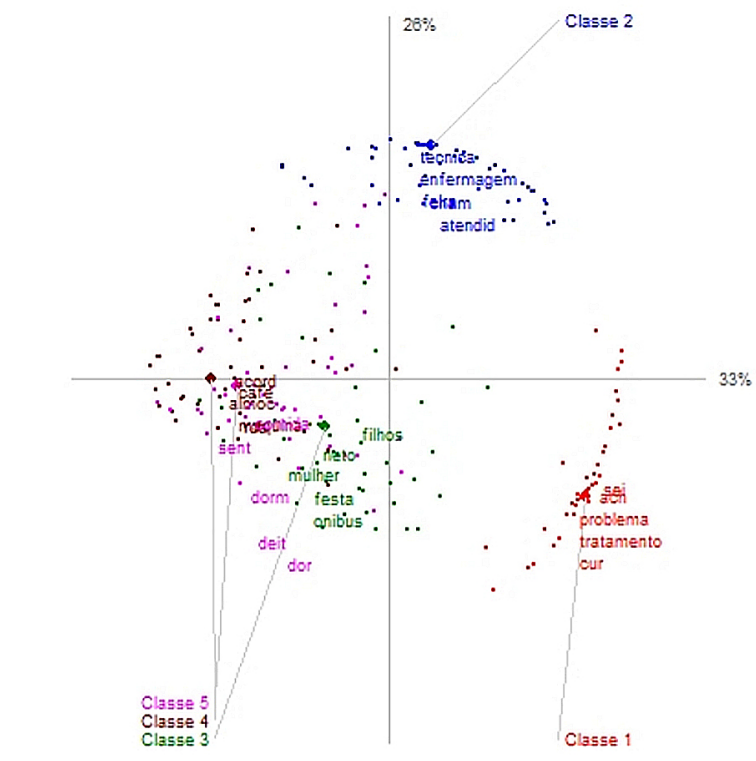

Caption: Class 1: tratamento- treatment; problema - problem; cura - healing; sei - know; acho - think. Class 2: enfermagem - nursing; atendida - assisted; técnica - technician; chama: call. Class 3: filhos - children; neto - grandchild; mulher - women; onibus - bus; festa - party. Class 4: acordo - wake; café- breakfast; almoço: lunch; máquina - machine. Class 5: sentado: seated; deitar-lying; dorme - sleeps; dor - pain; comida - food.

Source: Alceste report.

Figure 2 - Alceste Factorial Analysis of Correspondence, Rio de Janeiro, Rio de Janeiro, Brazil, 2018

This time, the chunk of Classes 3, 4 and 5 closest portrayed the discussion about the QoL of patients with vasculogenic ulcers from the impact of the disease on the daily lives of these patients, the difficulties faced and the effects of the disease on their lives. In turn, the chunk that brought together Classes 1 and 2 addressed the inclusion of patients in the healthcare service in search of treatment for their injury, with the contents of these two classes being the focus of this article, given the proposed objective. 
In Chart 1, there are the lexicons that integrated Classes 1 and 2 in the DHC, accompanied by the Phi value, followed by the total number in which they were mentioned in the corpus and their percentage in the class.

Class 1 was formed by 243 ECU and accounted for $56 \%$ of the textual corpus. It encompassed patients' discourse on the need to obtain a better life through the healing of their wounds, establishing the assessment of the healthcare service based on the search for specialized care. In the analysis of Chart 1, lexicons treatment and problem evidenced the need that patients reported to heal their wound (problem) through the achievement of a differentiated treatment, something that was not available in the service where they applied their dressings.

What I wanted was to get well, I wanted there to be a treatment, a solution, because we cannot pay, you are obliged to depend on the SUS, so I would very much like to have a solution for that. (ECU $\mathrm{n}^{\circ} 455$, Ind 21)

[...] but if I could have better treatment than what I have. Not that it's bad, but here it's just over the top, it gets a little better. (ECU $\mathrm{n}^{\circ} 485$, Ind 22)

Patient 22 defined care as "superficial" when he used the term "only from above", since, in the unit, he only performed the wound dressing, without getting any other specific treatment. This analysis is complemented by the lexicons live/wound, delay/ close. It is noticed that the limitations imposed by the wound prevented patients from defining their lives as something good; therefore, to live better, they need to find a treatment that will lead them to a cure.
Chart 1 - Alceste Descending Hierarchical Classification Classes, Rio de Janeiro, Rio de Janeiro, Brazil, 2018

\begin{tabular}{|c|c|c|c|c|c|c|c|}
\hline & & Class 1 & & & & Class 2 & \\
\hline Lexicon & Phi & Total number & Percent (\%) & Lexicon & Phi & Total number & Percent(\%) \\
\hline Think & 0.29 & 87 & 87 & Technician & 0.43 & 15 & 93 \\
\hline Problem & 0.23 & 31 & 100 & Nursing & 0.43 & 15 & 93 \\
\hline Treatment & 0.20 & 33 & 100 & Call & 0.38 & 9 & 100 \\
\hline Know & 0.19 & 56 & 83 & Fair & 0.29 & 12 & 80 \\
\hline Heal & 0.19 & 25 & 100 & Assisted & 0.29 & 7 & 88 \\
\hline Pain & 0.17 & 75 & 73 & Asked & 0.27 & 8 & 73 \\
\hline Better & 0.17 & 32 & 83 & Arrived & 0.26 & 5 & 100 \\
\hline Good & 0.16 & 21 & 95 & Monday & 0.26 & 8 & 100 \\
\hline Live & 0.16 & 47 & 87 & Friday & 0.24 & 7 & 75 \\
\hline Close & 0.15 & 38 & 82 & Ointment & 0.22 & 12 & 53 \\
\hline Person & 0.15 & 45 & 77 & Boot & 0.21 & 12 & 50 \\
\hline Lack & 0.14 & 25 & 85 & Change & 0.21 & 8 & 71 \\
\hline Wound & 0.14 & 59 & 72 & Bandage & 0.20 & 4 & 100 \\
\hline Angiology & 0.13 & 12 & 100 & Some & 0.20 & 6 & 60 \\
\hline Think & 0.13 & 16 & 89 & Serum & 0.20 & 4 & 80 \\
\hline Government & 0.13 & 12 & 100 & Father & 0.19 & 8 & 50 \\
\hline Concern & 0.10 & 12 & 90 & Did & 0.17 & 3 & 75 \\
\hline Physician & 0.12 & 68 & 70 & Oil & 0.17 & 3 & 75 \\
\hline Medicine & 0.11 & 45 & 71 & Mr. & 0.16 & 9 & 56 \\
\hline Condition & 0.12 & 10 & 100 & Said & 0.16 & 13 & 34 \\
\hline Complain & 0.12 & 18 & 85 & Came & 0.15 & 7 & 39 \\
\hline Money & 0.12 & 28 & 79 & Nurse & 0.15 & 8 & 39 \\
\hline \multicolumn{4}{|c|}{$\begin{array}{l}\text { Variables: female; } \\
\text { studied up to high school; } \\
\text { has between } 3 \text { and } 10 \text { years of injury; } \\
\text { not single; from } 51 \text { to } 70 \text { years of age. }\end{array}$} & \multicolumn{4}{|c|}{$\begin{array}{l}\text { Variables: male; not married; } \\
\text { studied up to elementary school; } \\
\text { has up to two years of injury; } \\
\text { over } 70 \text { years of aqe; has religion. }\end{array}$} \\
\hline
\end{tabular}

Source: Alceste report
If someone says they live well with a wound like this, I don't understand, because with this wound here there's no way, I can't do anything, I've even gotten used to it. (ECU $n^{\circ} 511$, Ind 23)

Just before this wound opened, the market closed and I was already out of work, so that was bad, because I couldn't even enter the INSS because I wasn't paying. And whoever is going to hire someone in this situation today, who is already in bad health, sick, imagine sick. To live well, to live better, there's no way, with this here, there's no way. (ECU n 529, Ind 24)

And it's one thing after another, this wound opened fast, when I saw it, it was already huge, now it's closing, it's getting better, but it takes so long, so I think that, to live well, you shouldn't have a wound like this. (ECU ${ }^{\circ} 530$, Ind 24)
No, it's impossible, there's no way to be happy like that, because living well and being happy, nobody can be happy being sick like that, without being able to do anything [...] I've been suffering from this wound for years and nobody can help me. It does interfere, yes, I've had this problem for fifteen years and I only retired five years ago, for ten years, I couldn't get a job. (ECU ${ }^{\circ}$ 609,616 , Ind 27)

Wound recurrence and long time of injury generate, considering the comings and goings of therapeutic itinerary, the search for someone to help them solve this problem. In this sense, the consultation, physician and angiologist lexicons referred to patients' desire to have a consultation with a specialist, someone who understands this subject. 
I needed a specialist physician, who doesn't have an angiologist here, to know the right treatment, the right medicine. It is difficult for a specialized physician to define better treatment, and better help from the government. (ECU $n^{\circ} 535$, Ind 24)

There's a lot missing, the medicine to get over this pain and move my day. Taking the pain away would be the most important thing to improve my life. Finding a physician who understands the subject, the angiologist, I've been through several physicians. (ECU $n^{\circ} 432$, Ind 20)

One of the aspects that patients scored was the lack of supplies, which impairs the healing of their wounds, as seen in the use of lexicons medicine, resource and material. Although many patients considered the care provided by professionals to be very good, the lack of input compromises the quality of the healthcare service.

I don't know, there should be more resources here, more material to help close, I think that's missing here. (ECU ${ }^{\circ} 20$, Ind 11)

As I was saying, lack is input, as you say. Material resources, there is no medicine, dressings, exams, I have been for more than a year to do an exam, I went downtown, closed that exam thing, I'm waiting and we wait for it, life passes and I never get well. (ECU $\mathrm{n}^{\circ} 556$, Ind 25)

Considering the difficulties and limitations of the healthcare service, the delay for the wound to heal, there was a feeling of hopelessness in some patients about the possibility of someone helping, with attachment to religion, to live with the wound.

You can't go to the beach, you can't be comfortable, I can't go to a pool, too many invitations you can't go, I can't. Losing my leg through this wound I have. There's only one person who can help me, God. To cure this here, just a miracle, there's no one who can help me. (ECU ${ }^{\circ} 320$, Ind 16)

In Class 2, the appearance of technical/nursing lexicons as those with the greatest association with this class allowed us to state that, in the relationship that patients establish with the healthcare service for treatment of their injury, nursing professionals were considered a reference. Thus, they were positively assessed by patients in the provision of care, particularly by a nursing technician in performing the dressing.

From here I have nothing to say, the first time I was hospitalized I came to the clinic, and they gave me antibiotics and I started to apply the dressings, the technician who makes the dressings called the physician and said, "It's very hot!". (ECU n ${ }^{\circ} 66$, Ind 03 )

The service is good, I'm always assisted, even on strike I came to get what I had here and they gave me, always the nursing technician who gives me things, changes the dressing here, moves there, uses this ointment, uses other [...]. (ECU n ${ }^{\circ} 657$, Ind 29)

It was also evidenced that the use of lexicons Monday/Friday/ Friday portrayed the daily routine of patients going to a Family Clinic to carry out their dressings. On weekends, patients themselves perform their dressings with the material provided by professionals.
And from Monday to Friday, here, Saturday, Sunday and on holidays, I have to bandage it at home. I do it myself, I just use the oil, here they put ointment, on Monday they have to come back here again, from Monday to Friday. (ECU $n^{\circ} 7$, Ind 01)

When I come, I take it and, at home, I do it Saturday and Sunday, but when I did it at my house before coming to the clinic, it was all inflamed, the foot was all bad, I don't know why, I bought sterile gloves, gauze, bandages [...]. (ECU n 169, Ind 10)

There was recognition of the importance of care provided by the nursing team and the positive clinical effects achieved from the use of techniques and technologies for the restoration of skin integrity by professionals, as seen in the use of lexicons ointment, boot, oil, serum, bandage, change. Thus, the improvement in symptoms and the regression of the evolution of the wound reflected the role of this professional in helping the wound to heal.

The neighbor said, "Go, now you can bandage it there!" I felt improvement, what she says, the pain has already improved. It hurt a lot, I used to do it at home, her ointment took away the pain a little, it got better. At home, I spent a lot, I bought that pack of gauze, l even bought the oil at the physicians' houses, ointment that is expensive [...]. (ECU $n^{\circ}$ 91, Ind 04)

The ointment I used, she said, "In a couple of days, you stop using it and start using the sunflower oil and that's it.". It's very important, every day I'm here in the morning, my daughter says every day, "Dad, have you been there? No, I'm going now!". She says, "Otherwise I'll get you if you don't go!" (ECU n ${ }^{\circ} 346$, Ind 17)

The wound has closed, it's great, that's all. In the medical area, nurses, psychologists are not necessary for me, you see, only in the area of the girls who take care of the dressing, the great nurses here, who help me a lot. (ECU n³98, Ind 19)

On the other hand, the assisted lexicon also approached nurse/hospital lexicons present in this class, and were related to the moments when there was some complication resulting from the wound that led patients to seek hospital care. The speeches denoted dissatisfaction with the service in such units.

I went to the hospital, I thought, they're going to admit me because I can't stand it, I was assisted in the triage by the nurse and she said that my case was Clínica da Gamilia, not even to give me a painkiller [...] I asked the nurse, "Aren't you even going to give me a medicine to improve my pain?" She said, "No!" In March, when the bullous erysipelas appeared, I went to the hospital, the physician who assisted me made me remove the bandage, I was alone. (ECU n ${ }^{\circ} 60 / 61$, Ind 03)

\section{DISCUSSION}

The data indicated that the reconfiguration of patients' lives based on the presence of ulcer guided the organization of their SR about QoL. This reconfiguration was explained by the presence and intensity of clinical manifestations of the disease, especially pain, which implied changes in daily activities. Thus, the construction of thoughts by patients about their QoL was guided by negative effects. 
When thinking about the dimension of affections in the elaboration of SR, it is highlighted that daily life generates a great affective mobilization. Affections are "the emotional coloration that permeates human existence and in particular the relationship with the world"(14). They include feelings, which include moods (anxiety, depression) and assessments (positive/negative); and emotions, a phenomenon that can interrupt the normal flow of cognition and action (fear/anger) ${ }^{(14)}$.

In turn, everyday thinking is built from the tension of daily situations, the people who will be present in these situations, the task to be performed, i.e., the pragmatic demands of social existence. On these occasions, the expression of thought in prescriptions and judgments is not indifferent to the other, on the contrary, it starts from the understanding that our actions will affect us because they will affect others. Thus, everyday life promotes affections, "which shakes us and puts us in another state of being, which pushes us to action"(14).

Affections occur, therefore, in the daily relationship with the world and with the other ${ }^{(14)}$. In the present research, patients with vasculogenic ulcers could not fully express themselves in this daily life, as they did not carry out activities independently, could not work or participate in social and leisure activities.

Therefore, starting from the understanding that the concept of QoL comprises a person's perception of the different dimensions of their life, considering the context in which they are inserted, their interests and values ${ }^{(1)}$, the presence of ulcer compromised the dimensions of being, belonging and becoming of patients' QoL. This explained their negative effects, given the loss of autonomy in the process of living arising from the reconfiguration of daily life with ulcer.

Thus, QoL was objectified in the image of "being happy", which meant independence to perform their activities. In turn, due to their condition, it resulted in the construction of an image of their QoL, which was the counterpoint of happiness. Objectification is one of the SR formation processes that assigns an imagery dimension to the object presented to understanding, so that what was unknown becomes something objective, naturalized, assuming the contours of reality, with concreteness, palpable. The imagery structure of SR becomes a reading guide and, by generalization, a reference theory to understand reality ${ }^{(15)}$.

These negative feelings that guided SR about QoL corroborate the results of other studies. One of them aimed to describe the negative social impacts and damage to the QoL of patients with chronic venous leg ulcers. The results showed that patients experienced negative feelings such as shame, loneliness, frustration, with higher levels of depression and anxiety ${ }^{(5)}$. Another investigation assessed anxiety, depression, self-esteem and loneliness in 102 patients with leg ulcers. Patients had higher scores on the anxiety and depression scale compared to healthy patients ${ }^{(6)}$.

In addition to the role of affections in the elaboration of $S R$, in order to understand the elements and relationships contained in a representation, one of the questions that must be answered is: "who knows, and from where do they know?", which leads to understanding SR production conditions, i.e., explain the meaning that the groups attribute to the represented object ${ }^{(15)}$.

Thus, we start from the understanding that every representation originates from "someone", who is a social subject, immersed in specific conditions of their space and time, referring to an object. The conditions of production express culture, in the broad and restricted sense, communication and language (intragroup, between groups and masses), and economic, institutional, educational and ideological insertion. Thus, the production conditions reaffirm the social mark of $\mathrm{SR}^{(15)}$.

In this research, analysis of production conditions falls on the social context of patients' insertion in relation to the healthcare service, with a view to deepening the psychosocial understanding of QoL. In this analysis, there were weaknesses in meeting the health demands of patients, which were related to difficulties in accessing a specialist physician, especially for the indication of appropriate therapy for ulcer healing.

This access difficulty was combined with infrastructure in relation to material resources, which resulted in a service that was classified by participants as superficial, with coverage changes and therapeutic choices that did not always have good results. With this lack of clinical results and the long wound time, some patients adopted more passive behaviors, unmotivated in taking care of themselves, in the belief that only a miracle could help.

On the other hand, there was an appreciation of monitoring by the nursing staff in the dressing room which, by using care techniques and technologies, contributed to the relief of symptoms, especially pain, improvement in the appearance of the injury and the establishment of bond with patients. In view of this recognition, some patients acted proactively by going to the clinic to apply the dressing and strengthening the bond with the team. It is pointed out, however, that the presence of a nurse in the dressing room only occurred when a specific change was identified that required injury assessment by this professional, which limited the potential of this professional to carry out multidisciplinary interventions with a view to improving patients' QoL.

For these reasons, the weaknesses in patient care at the healthcare service where they were registered were linked to the negative nature of the experience arising from daily difficulties with ulcer, which contributed to the negative effects that guided SR about QoL. To deepen the analysis of this data, research results are presented that confirm the difficulties in accessing specialized care for this clientele in healthcare services.

An example is the study that analyzed the offer of specialized consultations by SUS in a health region in Paraná State. One of the specialties with the greatest difficulty in accessing was the vascular one, considered to be non-existent/empty in care, a situation made worse by the lack of specialists, dependence on the private sector and reduced public participation in the provision of services ${ }^{(20)}$.

In an investigation that characterized the treatment of 58 patients with venous ulcers, $56,9 \%$ indicated that they received care from a nursing technician or assistant, a nurse and a physician; $24.1 \%$ received only from a nursing technician/assistant, without the participation of nurses; $8.6 \%$ were assisted exclusively by a nurse and a physician; and $7.0 \%$ received care only from a technician or assistant, with no assessment from a nurse and physician. Among those who had medical follow-up, $67.2 \%$ reported follow-up with an angiologist ${ }^{(21)}$.

In this context, the research reiterates the importance of the nursing team's role and, in particular, a nurse, in caring for this clientele. 
This is the case of investigation of the effect of health guidelines by nurses on the functional capacity of 16 people with venous ulcers followed up with dressings at home and guidelines on injury treatment. The reassessment consultation regarding patients' balance and gait indicated that of the nine domains that make up balance assessment, there was an improvement in eight of them. In gait, of the seven domains assessed, there was improvement in five of them. The guidelines provided an improvement in participants' QoL, enhancing their autonomy and social inclusion ${ }^{(22)}$.

This highlights the relevance of nurses' knowledge in the management of these patients, which have specificities according to the type of ulcer. Regarding this aspect, it is highlighted that arterial ulcer result from a complete or partial blockage of the arterial flow to the legs or feet, which causes ischemia and leads to wound formation. The injuries are deeper, with a yellowish base or necrosis, irregular shape and low exudate, causing claudication pain, worse at night and at rest, in addition to cold limbs and abnormal foot pulse ${ }^{(3)}$. In venous, the main etiological factor is chronic venous insufficiency due to valve incompetence, which triggers venous stasis, edema and leads to ulcer development. They are superficial, with the presence of granulation tissue and fibrin, moderate to high exudate, and throbbing pain that improves with rest ${ }^{(3)}$.

Therefore, it is understood that the role of nurses in this area can influence therapeutic success and the perception of QoL. On the other hand, the lower participation of nurses in direct work with patients and insufficient team preparation compromise the healing of injuries, contributing to the biopsychosocial suffering of patients and families, with impacts on $\mathrm{QoL}^{(23)}$.

This is what highlighted a research on the professional characteristics of 218 nursing workers who assisted people with vascular ulcers in dressing rooms. It was evident that, of this amount, 58.3\% had never been updated in the assessment and treatment of wounds, $40.7 \%$ with little experience in the area. Most nurses (90.6\%) participated only when called, with care provided by nursing technicians ${ }^{(23)}$.

Another survey signaled the importance of specialist training comparing the use of clinical information to manage venous ulcers and levels of accuracy when making diagnoses and judging the need for treatment between specialist nurses in skin integrity and generalists in community care in the UK. The use of clinical signs was similar in both groups, but experts were more accurate in judging diagnosis and treatment ${ }^{(24)}$.

\section{Contributions to health and nursing}

The SR identified portrayed the importance of healthcare professionals in assisting the subjective and objective health demands of patients with vasculogenic ulcers and the consequences of this assistance in the symbolic construction of QoL.
Thus, understanding such reflexes makes it possible to delineate actions with a view to improving patients' QoL so that this phenomenon can be redefined.

In this sense, given the social context, it is suggested to expand access to specialized medical care and, especially, expand the insertion of stomal therapy nurses, whose in-depth scientific knowledge and a comprehensive view of patients can contribute to the application of technologies in care nursing, with potential benefits to patients' QoL.

\section{Study limitations}

There was difficulty in capturing patients, due to the interruption of care at the unit studied, which limited the increase in the number of participants.

\section{FINAL CONSIDERATIONS}

The weaknesses in the context of healthcare for patients contributed to exacerbate the reconfiguration of daily life that the occurrence of ulcers implies due to the presence of pain and physical restrictions, influencing SR on the QoL of patients with vasculogenic ulcers. Thus, SR was marked by affections that expressed the counterpoint of happiness and actions that reflected, on the one hand, the desire for a better life and, on the other, lack of motivation in the face of lack of therapeutic results.

These results highlight the experience of patients with vasculogenic ulcers, their affections, the dimension of information and the meanings conferred by them from their life trajectory as well as their perspectives for action. Thus, they show that, despite being in large numbers within the health units, they still face the invisibility of their comprehensive care demands. This time, the data indicate the need to value the technical-instrumental demands of patients with vasculogenic ulcers that relate to the biological dimension of clinical therapy, but also to recognize the importance of interaction and listening in care in understanding the meanings given to the health-disease process experience to understand their ways of coping.

So, the information produced serves such professionals to qualify the assistance to patients affected by vasculogenic ulcers, starting from a critical reflection on the adoption of care attitudes committed to their well-being. Moreover, they encourage the development and application of care-education technologies that (re)construct information, affections and meanings based on stigmas, taboos and stereotypes, bringing improvements in the QoL of this clientele.

\section{FUNDING}

This study was financed in part by the Coordenação de Aperfeiçoamento de Pessoal de Nível Superior - Brasil (CAPES) - Finance Code 001

\section{REFERENCES}

1. Pereira EF, Teixeira CS, Santos A. Qualidade de vida: abordagens, conceitos e avaliação. Rev Bras Educ Fis Esporte. 2012;26(2):241-50. https:// doi.org/10.1590/S1807-55092012000200007

2. Joaquim FL, Silva RMCRA, Garcia-Caro MP, Cruz-Quintana F, Pereira ER. Impact of venous ulcers on patients' quality of life: an integrative review. Rev Bras Enferm. 2018;71(4):2021-9. https://doi.org/10.1590/0034-7167-2017-0516 
3. Agale SV. Chronic leg ulcers: epidemiology, aethiopathogenesis and management. Ulcers. 2013;2013:1-9. http:// doi. org/10.1155/2013/413604

4. Cruz CC, Caliri MHL, Bernardes RM. Epidemiological and clinical characteristics of people with venous ulcers attended at municipal health units. ESTIMA Braz J Enterostomal Ther. 2018;16:e1218. https://doi.org/10.30886/estima.v16.496

5. Platsidaki E, Kouris A, Christodoulou C. Psychosocial aspects in patients with chronic leg ulcers. Wounds. 2017;29(10):306-10. https://doi. org/10.25270/wnds/2017.10.306310

6. Kouris A, Armyra K, Christodoulou C, Sgontzou T, Karypidis D, Kontochristopoulos G, et al. Quality of life psychosocial characteristics in Greek patients with leg ulcers: a case control study. Int Wound J. 2016;13(5):744-7. https://doi.org/10.1111/iwj.12363

7. Peart J. Influence of psychosocial factors on coping and living with a venous leg ulcer. Br J Community Nurs. 2015;20(suppl 6):S21. https:// doi.org/10.12968/bjcn.2015.20.Sup6.S21

8. Lentsck MH, Baratieri T, Trincaus MR, Mattei AP, Miyahara CTS. Quality of life related to clinical aspects in people with chronic wound. Rev Esc Enferm USP. 2018;52:e03384. https://doi.org/10.1590/S1980-220X2017004003384

9. Salomé GM, Almeida SA, Pereira MTJ, Massahud Júnior MR, Moreira CNO, Brito MJA, et al. The impact of venous leg ulcers on body image and self-esteem. Adv Skin Wound Care. 2016;29(7):316-21. https://doi.org/10.1097/01.ASW.0000484243.32091.0c

10. Silva MH, Jesus MCP, Tavares RE, Caldeira EAC, Oliveira DM, Merighi MAB. Experience of adults and older people with adherence to venous ulcer care. Rev Gaucha Enferm. 2019;40:e20180024. https://doi.org/10.1590/1983-1447.2019.20180024

11. Tavares APC, Sá SPC, Oliveira BGRB, Sousa Al. Quality of life of elderly patients with leg ulcers. Esc Anna Nery. 2017;21(4):e20170134. https:// doi.org/10.1590/21779465EAN20170134

12. Castro A, Giacomozzi Al, Camargo BV. Representações sociais, zona muda e práticas sociais femininas sobre envelhecimento e rejuvenescimento. Estud Interdiscip Psicol. 2019;9(2):58-77. https://doi.org/105433/2236-64072016v9n1p58

13. Oliveira AC, Rocha DM, Bezerra SMG, Andrade EMLR, Santos AMR, Nogueira LT. Quality of life of people with chronic wounds. Acta Paul Enferm. 2019;32(2):194-201. https://doi.org/10.1590/1982-0194201900027

14. Arruda A. Meandros da teoria: a dimensão afetiva das representações sociais. In: Almeida AMO, Jodelet $D$, organizadores. Interdisciplinaridade e diversidade de paradigmas. Brasília, DF: Thesaurus; 2009. p 83-102.

15. Jodelet $D$, organizadora. As representações sociais. Rio de Janeiro: EdUERJ; 2001. Representações sociais: um domínio em expansão; p.17-44.

16. Wellborn J, Moceri JT. The lived experiences of persons with chronic venous insufficiency and lower extremity ulcers. J Wound Ostomy Continence Nurs. 2014;41(2):122-6. https://doi.org/10.1097/WON.0000000000000010

17. Monte BKS, Moura ECC, Costa JP, Silva GRF, Lopes VCA. Quality of life of patients with vasculogenic ulcers in outpatient treatment. Rev Rene. 2018;19:e3286. https://doi.org/1015253/217567832018193286

18. Enhancing the QUAlity and Transparency Of health Research. Equator-network.org [Internet]. University of Oxford; 2019[cited 2019 Aug 23]. Available from: http://www.equator-network.org/

19. Minayo MCS. Amostragem e saturação em pesquisa qualitativa: consensos e controvérsias. Rev Pesqui Qual [Internet]. 2017 [cited 2018 Jan 31];5(7):1-12. Available from: https://editora.sepq.org.br/rpq/article/view/82

20. Silva CR, Carvalho BG, Cordoni Jr L, Nunes EFPA. Difficulties in accessing services that are of medium complexity in small municipalities: a case study. Cienc Saude Colet. 2017;22(4):1109-20. https://doi.org/10.1590/1413-81232017224.27002016

21. Sant'Ana SMSC, Bachion MM, Santos QR, Nunes CAB, Malaquias SGM, Oliveira BGRB. Úlceras venosas: caracterização clínica e tratamento em usuários atendidos em rede ambulatorial. Rev Bras Enferm. 2012;65(4):637-44. https://doi.org/10.1590/\$0034-71672012000400013

22. Morais IM, Joaquim FL, Camacho ACLF. Efeito das orientações em saúde na capacidade funcional de pessoas com úlceras venosas. Rev Cubana Enferm [Internet]. 2017[cited 2019 Dec 12];33(2):11p. Available from: http://www.revenfermeria.sld.cu/index.php/enf/article/view/1082

23. Santana AC, Bachion MM, Malaquias SG, Vieira F, Carneiro DA, Lima JR. Caracterização de profissionais de enfermagem que atendem pessoas com úlceras vasculares na rede ambulatorial. Rev Bras Enferm. 2013;66(6):821-6. https://doi.org/10.1590/ S0034-71672013000600002

24. Adderley UJ, Thompson C. A comparison of the management of venous leg ulceration by specialist and generalist community nurses: a judgement analysis. Int J Nurs Stud. 2016;53:134-43. https://doi.org/10.1016/j.ijnurstu.2015.10.002 